JNPA. XXVI(1) 2012

\title{
Research \\ Evaluation of the phytochemical profile and uterine contractile effect of Woodfordia fruticosa (L.) Kurz and Dipsacus mitis D. Don
}

\author{
Rajendra Gyawali $^{1}$ * Deepak Jnawali ${ }^{2}$, Song Chang-Hun ${ }^{3}$, Kyong-Su Kim ${ }^{*} *^{4}$ \\ ${ }^{1)}$ Department of Pharmacy, Kathmandu University, Dhulikhel, Nepal \\ ${ }^{2)}$ Government of Nepal, Ministry of Forests and Soil Conservation, Babarmahal, \\ Kathmandu Nepal \\ 3) Department of Obstetrics and Gynecology, Chosun University, Seosuk-dong, \\ Gwangju 501-759, Republic of Korea \\ ${ }^{4)}$ Department of Food and Nutrition, Chosun University, Seosuk-dong, Gwangju \\ 501-759, Republic of Korea
}

\begin{abstract}
The phytochemical screening of Dipsacus mitis D. Don and Woodfordia fruticosa (L.) Kurz revealed the presence of bioactive secondary metabolites in both of the species but their concentrations were variable. Flavanoids and saponins were found in remarkable amount in both of the samples. The volatile compounds of both plants were extracted by Simultaneous Steam Distillation and Extraction (SDE) apparatus and analyzed by Gas Chromatography/Mass Spectrometery (GC-MS). Total 53 volatile compounds were tentatively identified from roots of Dipsacus mitis D. Don and 78 were identified from flowers of Woodfordia fruticosa (L.) Kurz. Alcohols were dominant in both the plants accounting $45 \%$ and $32 \%$ respectively. Numerous bioactive volatile compounds were detected in both herbs. The effects of increasing concentrations of the methanolic extracts on the amplitude and frequency of spontaneously contracting uterine tissues were tested. The effect of extracts on the smooth muscle strips from rat uterus showes the dramatic muscular relaxation on spontaneous contractility and was determided most effective at a concentration $6500 \mu \mathrm{g} / \mathrm{ml}$ of methanolic extract of Dipsacus mitis D.
\end{abstract}

Key words: Nepalese herbs, secondary metaboloites, GC-MS, uterine cell contractility

\section{Introduction}

An increasing reliance on the use of medicinal plants in the industrialized countries has been traced to the extraction and development of several drugs and chemotherapeutics from these plants as well as from traditionally used rural herbal remedies [1]. Wide molecular diversity of plant metabolites throughout the plant kingdom represents an extremely rich biogenic resources, some of them are synergistic, some antagonistic, some toxic and some inactive [2]. Today there are at least 120 distinct chemical substances derived from plants that are considered as important drugs currently in use in one or more countries in the world. To understand the actual value of plant remedies, several phytochemical surveys have been carried out which involved some plant accessions collected from all parts of the world. The major chemical substances of interest in these surveys have been the alkaloids, flavonoids, tannins, unsaturated sterols, triterpenoids, essential oils [3]. The majority of traditional medicines used in developing countries have not been evaluated for quality, safety, efficacy to same standards as those developed countries. Nevertheless, there are some remarkable claims made for their effectiveness during the practice of traditional medicines. Therefore the interest has given in scientifically validating the chemistry of plant drugs for dissolving the actual value of folkloric remedies, their efficacy and safety.

Ethnomedicinal knowledge persists, and is being transferred to the next generation in several parts of

*Corresponding author: Tel 011661399; Fax: 011661443; HP 977-9841714158

E-mail: gyawali@ku.edu.np or ragyawali@gmail.com

** Department of Food and Nutrition, Chosun University, Seosuk-dong, Gwangju

501-759, Republic of Korea, Email: kskim@ chosun.ac.kr 
Nepal [4]. It is estimated that only 12-20\% of the population living in around the urban area has access to the modern medicine facility and rest has to depend on the traditional medicine [5]. Crude-drugs are commonly given in the form of powder, decoctions, and infusions or in ointment forms. The herbal medicines are applied externally on cuts, wounds, boils, pimples, ringworms, muscular swelling and dislocation of bones. The single plant or plant parts such as root, rhizome, stem, leaf, bark, wood, gum, latex, ash, flower, fruit and seed, or admixture of different species of plants are recommended for treatment.

The plants Dipsacus mitis D. Don and Woodfordia fruticosa (L.) Kurz are reported in Nepalese literatures for their uses typically in pregnancy cases [6]. In recent past, much attention has been paid to record folk medicines of various tribal pockets and rural populations of Nepal. But the phytochemical screenings and biological activities of many of these herbs are quite poorly studied. Hence the investigation on phytochemical profiles and biological activities of Nepalese medicinal plants is in urgent need for the traditional medicinal herbs, therapeutic benefits and their possible toxic effects.

\section{Material and Methods}

\section{Collection and identification of plant materials}

Dried medicinal plants were collected from local market at Kathmandu, Nepal during 2006. All the plant samples were identified by the authors. The voucher specimens were also compared with the herbarium records of Department of Plant Resources, Royal Botanical Garden, Godawari, Nepal.

\section{Reagents}

All the reagents used in the experiments were purchased from Sigma Co. (USA) and Fisher Scientific (USA). The organic solvents used for the extraction and the chromatography were redistilled using a wire spiral packed double distilling apparatus (Normschliff Geratebau, Wertheim, Germany) and Milli-Q water that was generated through a water purification system (Millepore Corporation, Bedford, USA).

\section{Phytochemical screening}

The plant samples were grinded in a blender (MR 350CA, Braun, Spain) and used for the phytochemical screening test. Chemical testes were carried out on the aqueous and alcoholic extracts using standard procedures to identify the constituents as described in literatures [7-10].

\section{Volatile compounds}

Extraction of volatile organic compounds

Fifty grams of sample were homogenized in a blender (MR 350CA, Braun, Spain) and mixed with $1 \mathrm{~L}$ of distilled water. After adjusting the $\mathrm{pH}$ at 6.5 with $1 \% \mathrm{NaOH}, 1 \mu \mathrm{L} n$-butylbenzene was added as an internal standard. The resultant slurry was used for extraction of volatile organic compounds with $200 \mathrm{ml}$ redistilled $n$-pentane:diethylether $(1: 1, \mathrm{v} / \mathrm{v})$. The extraction of volatile organic compound was carried out for $2 \mathrm{~h}$, using simultaneous distillation-extraction (SDE) apparatus of Nikerson and Likens [11] type as modified under atmospheric pressure by Schultz et al [12]. The solvent, containing compounds extract, was dehydrated for $12 \mathrm{~h}$ using $10 \mathrm{~g}$ anhydrous $\mathrm{Na}_{2} \mathrm{SO}_{4}$ and then concentrated to approximately $1.5 \mathrm{~mL}$ using the vigreux column. This concentrate was further concentrated to $0.5 \mathrm{~mL}$ under gentle stream of $\mathrm{N}_{2}$ gas and used for gas chromatography-mass spectrometry (GC/MS) analysis.

\section{Chromatographic analysis}

Chromatographic analysis was carried out using a Shimadzu GC/MS (QP-5000, Shimadzu Co., Kyoto, Japan) in EI mode. The ionization voltage was $70 \mathrm{eV}$ and temperatures of ion source and injector were $230^{\circ} \mathrm{C}$ and $250^{\circ} \mathrm{C}$ respectively. The capillary column used was a DB-WAX $(60 \mathrm{~m}, \times 0.2 \mathrm{~mm}$, i.d., 0.25 
$\mu \mathrm{m}$, film thickness; $\mathrm{J} \& \mathrm{~W}$, USA). The oven temperature programmed at $40^{\circ} \mathrm{C}$ (Isothermal for 3 minutes) was ramped to $150^{\circ} \mathrm{C}$ at $2^{\circ} \mathrm{C} / \mathrm{min}$ and to $220^{\circ} \mathrm{C}$ at $4^{\circ} \mathrm{C} / \mathrm{min}(20 \mathrm{~min})$ followed by $230^{\circ} \mathrm{C}$ at $5^{\circ} \mathrm{C} / \mathrm{min}$. Helium was used as the carrier gas at a flow rate of $1 \mathrm{~mL} / \mathrm{min}$, with injector volume of $1 \mu \mathrm{L}$ using 1:20 split ratio.

Identification of volatile organic compounds

Qualitative analysis of volatile compounds was carried out by identification of compounds from mass spectra with the aid of mass spectral data books. The spectrum of each analyzed volatile compound agreed with that present in the mass spectrum library of WILLY 139, NIST 12 and NIST 62. The content of the volatile flavor compounds was calculated on a dry weight basis by comparing with peak area percent of the internal standard. The mass spectrometer scanned was ranged from 41 to $450 \mathrm{~m} / \mathrm{z}$.

\section{Biological activities}

Extraction of herb

Plant extracts were prepared using Accelerated Solvent Extractor (ASE 200). Total $50 \mathrm{~g}$ of samples were weighted and placed in the extraction cells in the oven of the instrument. Extraction was carried out at the temperature of $100{ }^{\circ} \mathrm{C}$ using methanol as extraction solvent. After the injection of the solvent into the cell, a pressurized static extraction phase lasting 5 min was carried out. After removal of the extracts (approx. $20 \mathrm{~mL}$ in each cell), they were filtered through a $0.45 \mu \mathrm{m}$ filter (Waters Millipore). The filtrate was evaporated to dryness using Rotavapour Apparatus (Buchi, Switzerland). Total $12.5 \mathrm{~g}$ and $10.25 \mathrm{~g}$ of $\mathrm{MeOH}$ extract obtained form the $50 \mathrm{~g}$ of Dipsacus mitis D. Don and Woodfordia fruticosa (L.) Kurz respectively.

\section{Determination of uterine smooth muscle cells contraction}

The PowerLab/4SP electroculograph is a data acquisition and analysis system was used for research. Uterine smooth muscle tissues were obtained from non-pregnant rats. The uterus of the rat was dissected and cut into $10 \mathrm{~mm}$ ring segments and placed immediately in Kreb's solution. The Kreb's solution had been cooled previously at $4^{\circ} \mathrm{C}$ and aerated with carbogen (95\% oxygen and 5\% carbon dioxide) to maintain a $\mathrm{pH}$ of 7.4. The uterine ring segments were suspended in organ bath filled with Kreb's solution. Each ring was suspended under an initial load of $2.0 \mathrm{~g}$ in $100 \mathrm{ml}$ organ baths containing Kreb's solution, temperature controlled at $37^{\circ} \mathrm{C}$ and continuously gassed with carbogen. The tissues were allowed to equilibrate for $1 \mathrm{~h}$ with Kreb's solution washing every 10-15 min. After spontaneous uterine contractile activity had been accomplished, plant extracts were added cumulatively to the bath. Changes in isometric force were measured continuously with a channel recorder (Model 79 F Polygraph; Grass Inst., Quincy, MA, USA) which was connected with preamplifier (7P5B, Grass Instr).

\section{Results and Discussion}

The phytochemical screening revealed the presence of medicinally active secondary metabolites in both of the species but their concentrations were variable (Table 1). Flavanoids and saponins were found in remarkable amount in both of the samples. The presence of saponins in Dipsacus species has been reported [13-14] which is in agreement with our results. It should be noted that steroidal saponin compounds are of importance and interest due to their relationship with such compounds as sex-hormones [15-16]. This could be one of the reason why the above plants are of vegetable for breast-feeding mothers to ensure their hormonal balance. Saponin bearing plants have hemolytic and anti-lipiemic activities and capacity to lower serum cholesterol levels can be considered to be their important characterstics [17]. Similarly, flavonoid rich species can play the role in pharmacological activities as anti-inflammatory, analgesic, anti-oxidant, antifungal and immunostimulant providing a key role of flavonoids to their biological actions [18]. Beside the flavonids and saponins, some other phytochemical groups were also detected in both of the samples. It is known that the plants which are rich in a wide variety of secondary metabolites belonging to chemical classes such as tannins, terpenoids, alkaloids, polyphenols are 
generally superior in medicinal activity as well as exhibit physiological activity. Most important bioactive constituents of the plants are alkaloids, tannins, flavonoids and phenolic compounds [19], those we found in our samles. Phytochemical screening of samples showed that both of the plants can stand for the medicinally important constituents. There was definite co-relation between the traditional application of plants and possession of secondary metabolites, which supports the scientific basis for the traditional medicinal system. This result may serve for future workers to select a group of plants having similar chemical constituents to isolate biologically active principle or to prepare remedies for particular case.

Table 1. Chemical Constituents of Some Species of Nepalese Medicinal Plants

\begin{tabular}{|c|c|c|c|c|c|c|c|}
\hline S.N. & Plant name & $\begin{array}{l}\frac{n}{0} \\
\frac{0}{3} \\
\frac{\pi}{3}\end{array}$ & $\begin{array}{l}\frac{0}{0} \\
0 \\
0 \\
0 \\
\frac{\pi}{I}\end{array}$ & $\begin{array}{l}\frac{0}{0} \\
\frac{0}{\infty} \\
0 \\
0 \\
0\end{array}$ & 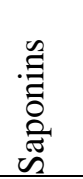 & $\begin{array}{l}\mathscr{\Xi} \\
\stackrel{\Xi}{\Xi} \\
\end{array}$ & $\begin{array}{l}\frac{n}{0} \\
\frac{0}{0} \\
\frac{0}{0} \\
\stackrel{0}{0}\end{array}$ \\
\hline 1 & Dipsacus mitis Wall. & - & ++ & - & +++ & - & + \\
\hline 2 & Woodfordia fructicosa (L.) Kurz & ++ & +++ & + & ++ & ++ & + \\
\hline
\end{tabular}

If the PPT is slight : +, Medium : ++, Heavy :+++, Not : -

The volatile compounds of Dipsacus mitis D. Don and Woodfordia fruticosa (L.) Kurz were extracted by solvent extraction (P:E,1:1) method for $2 \mathrm{~h}$ using SDE apparatus and analyzed by GC-MS. Compound 2butenal (8.77\%) $\alpha$-terpineol (6.52\%), hexanal (6.46\%), hexanol (5.59\%), 1,8-cineole (5.33\%), 2-heptanol (4.90\%), linalool (4.44\%) were detected as the major constituents of Dipsacus mitis D. Don while compounds furfural (11.05\%), linalool (8.04\%), 3-methyl butanal (6.76\%), heptadecanone $(5.40 \%)$, $\alpha$ terpeniol (4.96\%), undecanoic acid (3.89\%) were detected as the major constituents of Woodfordia fruticosa (L.) Kurz. Result showed that rhizomes of Dipsacus mitis D. Don contained $61.93 \mathrm{mg} / \mathrm{kg}$ volatile compounds and Woodfordia fruticosa (L.) Kurz contained $224.98 \mathrm{mg} / \mathrm{kg}$ volatile compounds (dry weight basis). Total 53 volatile compounds were tentatively identified from Dipsacus mitis D. Don and 78 were identified from Woodfordia fruticosa. Alcohols were dominant in both the plants, Dipsacus mitis D. Don accounting with $45 \%$ and Woodfordia fruticosa (L.) Kurz accounting with $32 \%$.

Table 2. Relative content of functional groups of volatile organic compounds identified in Dipsacus mitis D.Don

\begin{tabular}{clcccc}
\hline \hline \multirow{2}{*}{ No. } & Functional group & \multicolumn{2}{c}{ Dipsacus mitis D.Don. } & \multicolumn{2}{c}{ Woodfordia fruticosa (L.) } \\
\cline { 3 - 6 } & & $\begin{array}{c}\text { Area } \\
(\%)\end{array}$ & $\begin{array}{c}\text { Number of } \\
\text { compounds }\end{array}$ & $\begin{array}{c}\text { Area } \\
(\%)\end{array}$ & $\begin{array}{c}\text { Number of } \\
\text { compound }\end{array}$ \\
\hline \hline 1 & Acid & 6.10 & 4 & 17.01 & 9 \\
2 & Alcohol & 45.77 & 21 & 32.20 & 24 \\
3 & Aldehyde & 29.64 & 14 & 30.44 & 15 \\
4 & Ester & 2.95 & 2 & 2.88 & 4 \\
5 & Furan & 2.56 & 3 & 1.48 & 3 \\
6 & Hydrocarbon & - & - & 5.39 & 9 \\
7 & Ketone & 8.62 & 6 & 9.30 & 8 \\
8 & N-Compound & 4.21 & 3 & 1.30 & 6 \\
\hline \hline
\end{tabular}




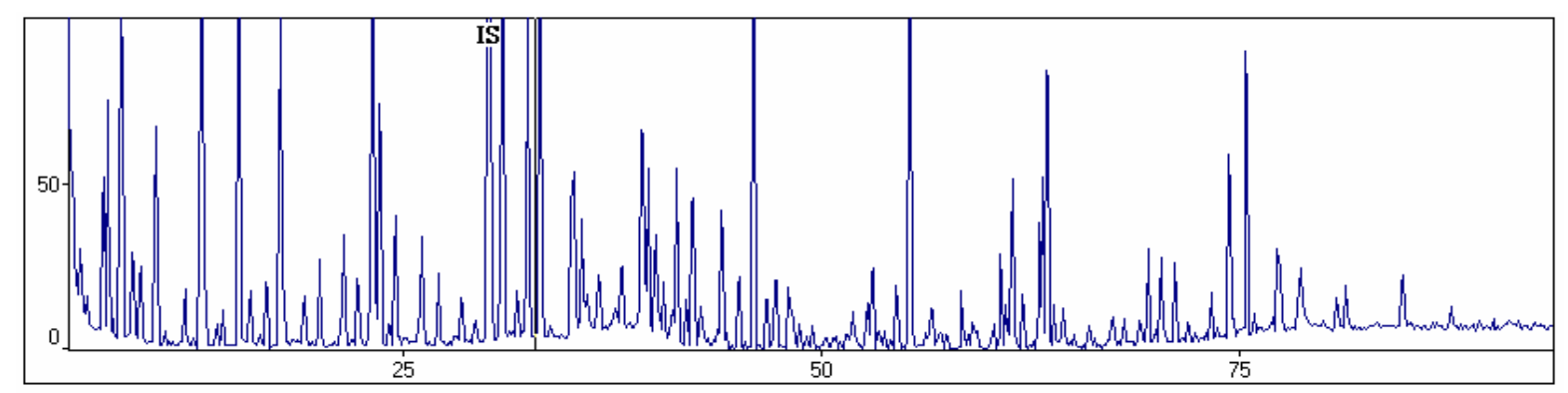

Figure 1. GC/MS total ion chromatograms of volatile components in Dipsacus mitis D.Don.

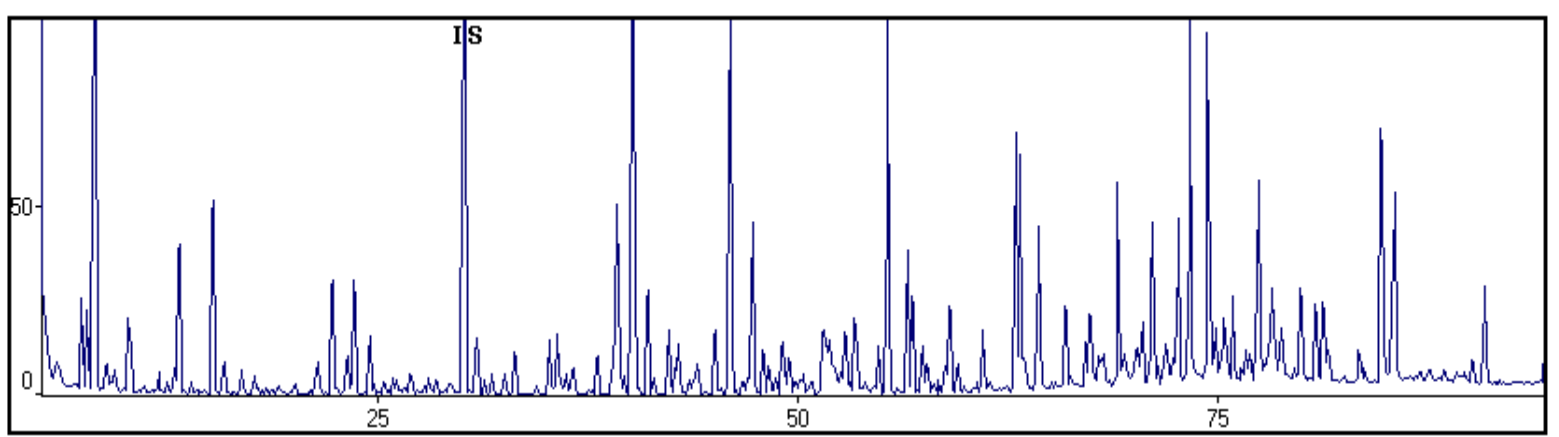

Figure 2 . GC/MS total ion chromatogram of volatile organic compounds of Woodfordia fructicosa

\section{(L) Kurz extract.}

Numerous bioactive volatile compounds were detected in these herbs and their characteristics are discussed in this paper. The most abundant compound furfural has a wide variety of uses such as weed killer, fungicide, affects yeast survival and also affects biochemical enzyme activities [20]. Linalool, a major compound of this oil, is known for various pharmacological activities as well as it is important substance used in foodstuffs as a food additives [21]. The compounds linalool, $\alpha$-terpineol, geraniol were major oxygenated monoterpenes while farnesol, $[Z]$-Nerolidol were the major oxygenated sesquiterpene. Monoterpenes are generally regarded as safe substances. $\alpha$-Terpineol is probably the most important of the monocyclic monoterpene alcohol possessing various biological activities and flavor compositions [22]. 4-Terpinenol, which occurs in appreciable amounts in this oil, is also reported to show activity against the microorganisms [23]. Geraniol, exerts anti-tumor activity against various cancer cells both in vitro and in vivo [24]. Consequently monoterpene phenols were previously reported to be active against fungi [3] and can be used as alternative sprout inhibitors [25]. Pharmacologically active some compounds related to hydrocarbon sesquiterpenes such as $(E)$-caryophyllene, $\alpha$-humulene were detected in this study which have been claimed to contain the antibacterial, antifungal or antioxidant properties [26]. Plant oils containing monoterpene hydrocarbons including $\beta$-Myrcene are used as flavoring additives in foods and beverages, as fragrances in cosmetics, and as scent in household products [27]. Safrole has been used as a topical antiseptic and it is carcinogenic to the liver so it is no longer used as a flavoring agent in foods. Farnesol is a precursor of vitamin $\mathrm{E}$ and $\mathrm{K} 1$, modulates cholesterol synthesis is metabolized to steroids in retina [28]. The presence of pyrazine compounds in many plant species results from Maillardtype nonenzymetic reactions between reducing sugars and free amino acid or amide. The pyrazine compounds impart a reportedly nut-like aroma. Compounds $\alpha$-terpineol, linalool, furfural and geraniol were common in both herbs. 
JNPA. XXVI(1) 2012

Table 3. Volatile Organic Compounds of Dipsacus mitis D.Don. and Woodfordia fruticosa (L.) Kurz

\begin{tabular}{|c|c|c|c|c|}
\hline No. & $\mathbf{R I}^{\mathbf{b})}$ & Compound Name & $\begin{array}{c}\text { Dipsacus mitis } \\
\text { Content }(\%) \\
\end{array}$ & $\begin{array}{c}\text { Woodfordia fruticosa } \\
\text { Content }(\%)\end{array}$ \\
\hline 1 & 850 & Butanal & 1.30 & - \\
\hline 2 & 862 & Ethyl acetate & 2.48 & 0.81 \\
\hline 3 & 871 & 2-Methylbutanal & 0.03 & 2.84 \\
\hline 4 & 878 & 2-Butanone & - & 0.70 \\
\hline 5 & 896 & 3-Methylbutanal & 3.14 & 6.76 \\
\hline 6 & 922 & Ethanol & 0.98 & 0.26 \\
\hline 7 & 938 & 2-Ethylfuran & 0.60 & 0.21 \\
\hline 8 & 967 & 2,3-Butanedione & - & 0.64 \\
\hline 9 & 969 & 2-Pentanone & 3.05 & - \\
\hline 10 & 970 & Pentanal & - & 0.53 \\
\hline 11 & 1036 & 2-Butenal & 8.77 & 0.28 \\
\hline 12 & 1040 & 2,3-Dihydrofuran & 0.89 & - \\
\hline 13 & 1041 & 4-Heptanone & - & 1.34 \\
\hline 14 & 1079 & Hexanal & 6.46 & 1.73 \\
\hline 15 & 1090 & 2-Methylpropanol & 0.53 & 0.26 \\
\hline 16 & 1107 & 3-Pentanol & 0.50 & - \\
\hline 17 & 1121 & 2-Pentanol & 2.66 & - \\
\hline 18 & 1124 & {$[E]$-2-Pentenal } & 0.50 & - \\
\hline 19 & 1146 & Butanol & 0.27 & 0.09 \\
\hline 20 & 1161 & $\beta$-Myrcene & - & 0.15 \\
\hline 21 & 1179 & 2-Heptanone & 0.16 & 0.19 \\
\hline 22 & 1181 & Pyridine & 1.05 & - \\
\hline 23 & 1193 & Heptenal & 0.56 & 0.27 \\
\hline 24 & 1206 & 1,8-Cineole & 5.33 & - \\
\hline 25 & 1207 & 2-Methylbutanol & 1.59 & 0.33 \\
\hline 26 & 1213 & 2-Hexenal & 2.11 & 1.10 \\
\hline 27 & 1228 & 2-Pentylfuran & 1.07 & 0.47 \\
\hline 28 & 1252 & Pentanol & 1.12 & 0.33 \\
\hline 29 & 1264 & Methylpyrazine & - & 0.19 \\
\hline 30 & 1279 & $\alpha$-Terpinene & - & 0.10 \\
\hline 31 & 1285 & Octanal & 0.41 & 0.10 \\
\hline$I S$ & 1310 & Butylbenzene & 0.00 & - \\
\hline 32 & 1321 & 2-Methyltetrahydrofuran & - & 0.80 \\
\hline 33 & 1322 & 2-Heptanol & 4.90 & - \\
\hline 34 & 1328 & 2,3-Dimethylpyrazine & - & 0.12 \\
\hline 35 & 1335 & 6-Methyl-5-hepten-2-one & 0.36 & 0.19 \\
\hline 36 & 1344 & 2-Octanol & 3.09 & - \\
\hline 37 & 1356 & Hexanol & 5.92 & 0.43 \\
\hline 38 & 1382 & 4-Ethylpyridine & 1.51 & - \\
\hline 39 & 1384 & 3-Hexenol & 1.67 & 0.53 \\
\hline
\end{tabular}


JNPA. XXVI(1) 2012

\begin{tabular}{|c|c|c|c|c|}
\hline 40 & 1390 & Nonanal & 1.05 & 0.67 \\
\hline 41 & 1398 & Tetradecane & - & 0.15 \\
\hline 42 & 1403 & Trimethylpyrazine & - & 0.31 \\
\hline 43 & 1405 & 2-Hexenol & 0.39 & - \\
\hline 44 & 1427 & 5-Methylhexanol & - & 0.36 \\
\hline 45 & 1446 & {$[Z]$-Linalool oxide } & & 3.33 \\
\hline 46 & 1446 & Acetic acid & 2.70 & - \\
\hline 47 & 1452 & 3-Decanone & - & 0.21 \\
\hline 48 & 1452 & 1-Octen-3-ol & 1.40 & - \\
\hline 49 & 1459 & Furfural & 1.00 & 11.0 \\
\hline 50 & 1473 & {$[E]$-Linalool oxide } & - & 1.02 \\
\hline 51 & 1477 & 4-Ethyenylpyridine & 1.66 & - \\
\hline 52 & 1478 & Tetramethylpyrazine & - & 0.12 \\
\hline 53 & 1491 & {$[E, E]-2,4-$ Heptadienal } & 1.24 & - \\
\hline 54 & 1492 & 2-Ethylhexanol & 1.57 & 0.90 \\
\hline 55 & 1500 & 2-Acetylfuran & - & 0.63 \\
\hline 56 & 1510 & Pyrrole & - & 0.19 \\
\hline 57 & 1518 & Benzaldehyde & 1.45 & - \\
\hline 58 & 1519 & Benzaldehyde & - & 0.36 \\
\hline 59 & 1535 & 2-Nonenal & - & 0.67 \\
\hline 60 & 1535 & Octanol & 0.54 & - \\
\hline 61 & 1549 & Linalool & 4.44 & 8.04 \\
\hline 62 & 1569 & 5-Methylfurfural & - & 2.13 \\
\hline 63 & 1569 & 3,5-Octadien-2-one & 0.48 & - \\
\hline 64 & 1580 & Linalool acetate & 0.47 & - \\
\hline 65 & 1583 & {$[E, Z]-2,6$-Nonadienal } & - & 0.22 \\
\hline 66 & 1595 & $\beta$-Caryophyllene & - & 0.52 \\
\hline 67 & 1602 & 4-Terpineol & & 0.33 \\
\hline 68 & 1625 & Butanoic acid & - & 0.10 \\
\hline 69 & 1636 & Benzeneacetaldehyde & - & 1.73 \\
\hline 70 & 1657 & Furfuryl alcohol & - & 0.73 \\
\hline 71 & 1662 & Nonanol & 0.77 & - \\
\hline 72 & 1666 & 3-Methyl butanoic acid & - & 1.55 \\
\hline 73 & 1689 & $\alpha$-Humulene & - & 0.48 \\
\hline 74 & 1697 & $\alpha$-Terpineol & 6.52 & - \\
\hline 75 & 1698 & $\alpha$-Terpineol & - & 4.96 \\
\hline 76 & 1720 & Junipene & - & 1.71 \\
\hline 77 & 1725 & Caryophyllene & - & 1.15 \\
\hline 78 & 1736 & Pentanoic acid & - & 0.63 \\
\hline 79 & 1761 & {$[Z, E]-\alpha$-Farnesene } & - & 0.28 \\
\hline 80 & 1765 & Epoxylinalol & - & 0.89 \\
\hline 81 & 1773 & Methyl salicylate & - & 0.28 \\
\hline 82 & 1799 & Nerol & - & 0.64 \\
\hline
\end{tabular}




\begin{tabular}{cclcc}
83 & 1809 & {$[E, E]-2,4-D e c a d i e n a l$} & 1.67 & - \\
84 & 1844 & Hexanoic acid & 1.33 & 2.87 \\
85 & 1849 & {$[E]$-Geraniol } & 1.29 & 2.33 \\
86 & 1856 & {$[E]$-Gerayl acetone } & 1.99 & - \\
87 & 1874 & Safrole & - & 1.79 \\
88 & 1876 & Benzyl alcohol & 0.36 & 0.57 \\
89 & 1912 & Benzeneethanol & - & 0.85 \\
90 & 1951 & Heptanoic acid & - & 0.80 \\
91 & 1974 & 2-Acetylpyrrole & - & 0.37 \\
92 & 1995 & [Z]-Nerolidol & - & 2.23 \\
93 & 2038 & Farnesol & - & 0.43 \\
94 & 2055 & Octanoic acid & 0.54 & 1.47 \\
95 & 2111 & Heptadecanone & - & 5.40 \\
96 & 2130 & Nonanoic acid & 1.53 & 3.64 \\
97 & 2134 & Eugenol acetate & - & 1.06 \\
98 & 2148 & 3-Methoxyacetophenone & 2.60 & - \\
99 & 2150 & Tetradecanol & - & 0.56 \\
100 & 2157 & Methyl nonanoate & - & 0.74 \\
101 & 2184 & Decanoic acid & - & 2.06 \\
102 & 2197 & Docosane & - & 0.85 \\
103 & 2373 & Undecanoic acid & - & 3.89 \\
\hline \hline
\end{tabular}

We studied the effect of the different plant extracts on the smooth muscle strips from rat uterus. The effects of increasing concentrations of the extracts on the amplitude and frequency of spontaneously contracting uterine tissues were tested. Dramatic muscular relaxation on spontaneous contractility was obtained at a concentration of $6500 \mu \mathrm{g} / \mathrm{ml}$ of Dipsacus mitis D. Don slight relaxation on spontaneous contractility was obtained by methanol extract of Woodfordia fruticosa (L.) Kurz upto concentration of $20000 \mu \mathrm{g} / \mathrm{ml}$. Frequency of contraction in both cases was decreased as dose of drug was increased. The inhibition of Kreb's solution induced contraction could be due to an effect on one of the components of the vessel wall, namely the endothelium, the smooth muscle, or the extracellular matrix. 


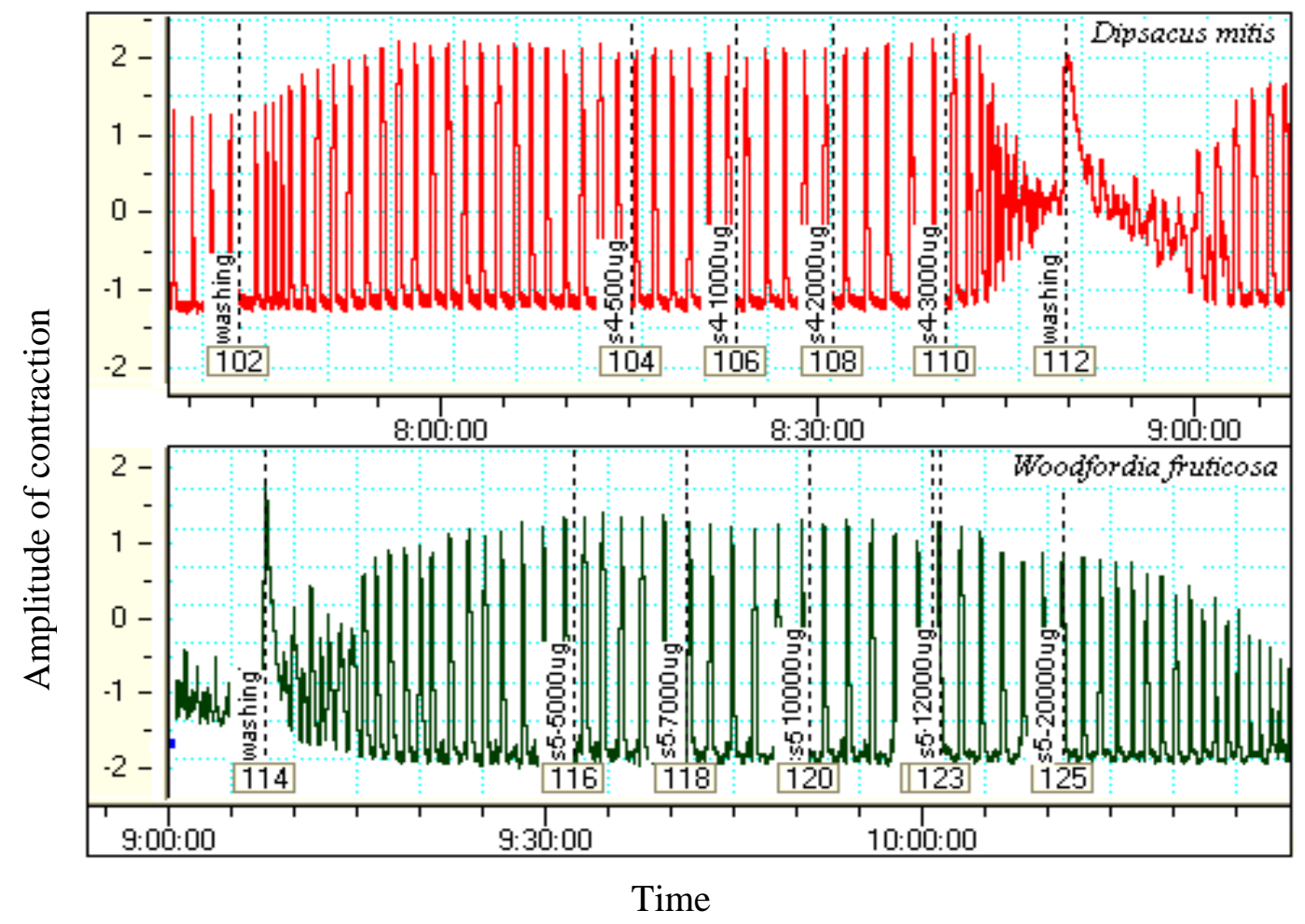

Fig. 3. Effect of methanol extracts of Dipsacus mitis D. Don and Woodfordia fruticosa (L.) Kurz on uterine smooth muscle tissues of non-pregnant rat

After loading the tissue, the system was operated for 30 minutes in Krab's solution to check and maintain contractibility. Normal Kreb's solution caused a significant contraction that reached a maximum within few minutes. Kreb's solution contains numerous nutrituents such as $\mathrm{NaCl}, \mathrm{KCl}, \mathrm{MgCl}_{2}, \mathrm{KH}_{2} \mathrm{PO}_{4}$, $\mathrm{NaHCO}_{3}, \mathrm{CaCl}_{2}$ and Glucose. These nutrituents made cell active and could be seen on polygraphs. The observed inhibition of vascular contraction after adding $\mathrm{MeOH}$ extract was result of an effect of plant secondary metabolites. Effective weight $6,500 \mu \mathrm{g}$ of plant is equivalent to $317 \mathrm{mg}$ of its raw weight and $20,000 \mu \mathrm{g}$ equivalent to $975 \mathrm{mg}$ of its raw weight. This result appears to justify their traditional uses and give additional interest that these plants could be useful for controlling the preterm birth problem. For further confirmation and accurate report, dose dependent steps, in-vivo and in-vitro tests, ion-channel studies and more pre-clinical studies should be done. We concluded that inhibited spontaneous induced uterine smooth muscle contraction by $\mathrm{MeOH}$ extract of Dipsacus mitis D. Don and Woodfordia fruticosa (L.) Kurz justify their traditional uses. Dipsacus mitis D. Don is possesses the least relaxation effect in rat uterine smooth muscles.

\section{Acknowledgement}

I would like to acknowledge to Prof. Kim Kyong-Su, Department of Food and Nutrition; and Prof. , Song Chang-Hun, Department of Obstetrics and Gynecology of Chosun University, Republic of Korea for the kind guideline and research facility. 


\section{References}

1. UNESCO. FIT/504-RAF-48.Terminal Report: Promotion of Ethnobotany and the Sustainable Use of Plant resources in Africa. Paris. p. 60, 1998.

2. Alonso Paz E, Cerdeiras MP, Fernadez J, Ferreira F, Moyna P, Soubes M, Váquez A, Vero S, Zunino L. Screening of Uruguayan medicinal plants for antimicrobial activity. Journal of Ethnopharmacology 20: 67-69, 1995.

3. Farnsworth NR, Akerele O, Bingel AS, Soejarto DD and Guo Z. Bull. WHO 63: 964-981, 1985.

4. Shrestha KK, Tiwari NN and Ghimire SK. MAPDON-Medicinal and Aromatic Plants Database of Nepal. In proceeding of Nepal-Japan joint symposium on conservation and utelization of Himilayan medicinal Plants, November 6-11, Nepal, PP 53-74, 2000.

5. Manandhar NP. Medicinal folk-lore about the plants used as anthelmintic agents in Nepal. Fitoterapia 66(2): 149-155, 1995.

6. HMGN. Medicinal plants of Nepal, Bulletin of Department of Medicinal Plants, no. 10, His Majesty's Government, Nepal, 1970.

7. Harborne JB. 1973. Phytochemical methods, London. Chapman and Hall, Ltd.

8. Salehi Surmaghi MH, Aynehchi Y, Amin GH and Mahmoodi Z. 1992. Survey of Iranian plants for saponins, alkaloids, flavonoids and tannins. IV. Daru 2: 281-291.

9. Rizk AM. 1982. Constituents of plants growing in Qatar. I. A chemical survey of six plants. Fitotherapia 52: 35-44.

10. Somolenski SJ, Silinis H and Farnsworth NR. 1974. Alkaloid screening. I. Lloydia 536.

11. Nikerson GB, Likens ST. Gas chromatography evidence for the occurrence of hop oil components in beer. J Chromatogr 21: 1-5, 1966.

12. Schultz TH, Flath RA, Mon TR, Enggling SB, Teranishi R. Isolation of volatile components from a model system. J Agric Food Chem 25: 446-449, 1977.

13. Suh HW, Song DK, Son KH, Wie MB, Lee KH, Jung KY, Do JC, Kim YH. Antinociceptive mechanisms of dipsacus saponins $\mathrm{C}$ administered intracerebro-ventriculary in the mouse. Gen. Pharmac. 27 (7): 1167-1172, 1996.

14. Hung TM, Jin WY, Thuong PT, Song KS, Seong YH, and Bae KH. Cytotoxic Saponins from the Root of Dipsacus asper Wall Arch Pharm Res 28(9): 1053-1056. 2005.

15. Okwu DE. Evaluation of chemical composition of indigenous spices and flavouring agents. Global J. Pure Apple. Sci. 7 (3): 455-459, 2001.

16. Singh S, Shakya KS, Keshri G, Antifertility effect of dipsacus mitis collected in Phulchoki, Nepal. In: Proceeding of Nepal-Japan Joint Symposium on conservation and utilization of Himalayan Medicinal Plants. Pp 127-129, 2000. 
17. Sidhu GS and Oakenfull DG. A mechanism for the hypocholestrolemic activity of saponins. $\mathrm{Br} J$ Nutr 55: 643-649, 1986.

18. Havsteen B. Flavonoids, a class of natural products of higher pharmacological potency. Biochemical Pharmacology 32: 1114-1148, 1983.

19. Hill AF. Economic Botany. A textbook of useful plants and plant products. $2^{\text {nd }}$ edn. McGarw-Hill Book Company Inc, New York. 1952.

20. Schultes RE and Raffauf RF. The Healing Forest Dioscorides Press, Portland. 1990.

21. Tyler VE. Phytomedicines: Back to future, J. Nat. Prod., 62:1589-1592, 1999.

22. Arvigo R and Balick M. Rainforest Remedies, Lotus Press, Twin Lakes,

ISBN: 0914955136, 1993.

23. Saxana RC. Ethnomedicinal used of neem and future prospects .in: Recent progress in medicinal plants 7: 1-14, 2003.

24. Harborne JB, Baxter H, and Moss P. Phytochemical dictionary- A handbook of bioactive compounds from plants, Taylor and Francis, London, 1999.

25. Alonso Paz E, Cerdeiras MP, Fernadez J, Ferreira F, Moyna P, Soubes M, Váquez A, Vero S, Zunino L. Screening of Uruguayan medicinal plants for antimicrobial activity. Journal of Ethnopharmacology 20: 67-69, 1995.

26. Gupta SS. Prospects and perspectives of natural plant products in medicine. Ind. J. Pharmacol. 26: 1-2, 1994.

27. Clardy J, Walsh C. Lessons from natural molecules. Nature 432: 829- 837, 2004.

28. Nicolaou KC, Snyder SA. The essence of total synthesis. Proceedings of the National Academy of Sciences of the United States of America, 101: 11929- 11936, 2004. 